\title{
WIF1 wt Allele
}

National Cancer Institute

\section{Source}

National Cancer Institute. WIF1 wt Allele. NCI Thesaurus. Code C97868.

Human WIF1 wild-type allele is located in the vicinity of 12q14.3 and is approximately 71 $\mathrm{kb}$ in length. This allele, which encodes Wnt inhibitory factor 1 protein, is involved in the regulation of Wnt signaling pathways. 